\title{
PENGARUH MOTIVASI KERJA DAN IKLIM ORGANISASI TERHADAP KINERJA PEGAWAI PADA LEMBAGA PENJAMINAN MUTU PENDIDIKAN PROVINSI SULAWESI TENGGARA
}

Oleh:

\author{
Muhammad Basri' ${ }^{1}$, Abdul Kadir2, \\ 1,2Depatement of Public Administration, Universitas Halu Oleo, Kendari \\ E-mail: ${ }^{1}$ muhammadbasri275@gmail.com, ${ }^{2}$ Habdulkadir64@yahoo.com
}

\begin{abstract}
The Problem that will be worked through deep observational are aff motivation effect and organization climate to employee performance at Educational Quality Guarantee Institute of Southeast Sulawesi Province. This research variables analyze motivation which cover incentifcation dimension, employee placement appropriately, attention to employee self-respect, attention to work condition and give chance to go forward,. Whereas, variable of Organizational climate cover privacy aspect and acclimatization harmony, reward on employee work and their job clarity. While, employee performance cover jobsharpness. There is dimension even of clerk performance cover job quality, job quantity and also work time timing. Population in this reserarch is overall of employee which amount 123 person, and this research design use data collection technic by use of questioner, interview and documents study. Whereas data analysis to hypothesis test by use of double linear regression analysis and partial analysis uses $t$-tests $t$ and simultan analysis uses $f$-test The result of this research pointed out that 1) Motivation was positively influence to employee performance. 2) Organizational Climate was positively influence to employee performance. 3) Motivation and organizational climate positive ly influence toward employee performance simultaneously on Educational Quality Guarantee Institute of Southeast Sulawesi Province as big as 27,30\%. Meanwhile, 72,70\% regarded by other factors.
\end{abstract}

Keywords: Motivation, Organizational climate, and employee performance 


\section{LATAR BELAKANG}

Kedudukan dan peranan pegawai negeri sipil sebagai unsur pegawai Negara yang bertugas sebagai abdi masyarakat harus menyelenggarakan pelayanan secara adil kepada masyarakat dengan dilandasi kesetiaan dan ketaatan kepada Pancasila dengan Undang-Undang Dasar 1945. Untuk dapat melaksanakan tugas dengan baik, maka motivasi pegawai harus dibangkitkan, hal ini dapat difahami karena motivasi merupakan titik sentral dan motor penggerak bagi tumbuhnya inspirasi, inisiatif dan kreativitas untuk bekerja lebih baik yang akan bermuara pada kinerja yang baik. Hal ini menggambarkan keterkaitan yang erat antara motivasi dengan kinerja.

Pemberian motivasi dapat diamati dari dimensi pemberian insentif, penempatan pada bidang yang sesuai, perhatian terhadap lingkungan kinerja, perhatian terhadap harga diri serta kesempatan untuk maju. Pemberian insentif berkaitan dengan pemberian bonus sewaktu-waktu karena usaha dan prestasi kerja pegawai. Seorang pemimpin harus dapat memberikan rangsangan untuk membangkitkan gairah kerja karyawan serta memberikan penghargaan atas hasil kerja pegawai. Penempatan pada bidang yang sesuai berkaitan dengan jenjang pendidikan, pengalaman kerja, memberikan kontribusi pada instansi dan diperhatikan atasan serta pimpinan memberikan beban pekerjaan sesuai dengan kemampuan pegawai. Perhatian terhadap harga diri berkaitan dengan pimpinan yang selalu memberikan penjelasan kepada bawahan tentang pelaksanaan pekerjaan untuk menciptakan iklim yang kondusif. Perhatian terhadap lingkungan kerja berkaitan dengan fasilitas kerja yang digunakan oleh pegawai. Pemberian kesempatan untuk maju berkaitan dengan upaya pimpinan untuk mengembangkan pengetahuan, kemampuan dan keterampilan dan pengusulan diklat yang dilaksanakan sesuai dengan job dan promosi untuk kenaikan pangkat dan golongan.

Selain pemberian motivasi seperti diuraikan tersebut, iklim organisasi juga merupakan salah satu faktor yang dapat mempengaruhi kinerja pegawai. Iklim organisasi berkaitan dengan keleluasan penyesuaian diri, penghargaan atas kerja yang baik, dan kejelasan pekerjaan. Keleluasan penyesuaian diri adalah keleluasaan pegawai untuk melakukan penyesuaian waktu pelaksanaan tugas, keleluasaan pegawai untuk melakukan penyesuaian prosedur kerja. Penghargaan atas kerja yang baik adalah pimpinan organisasi yang menyediakan insentif, menyediakan pengakuan yang normatif bagi yang bekerja dengan baik. Kejelasan pekerjaan adalah kejelasan uraian tugas dan kejelasan hasil yang diharapkan dari pelaksanaan tugas. Jika hal-hal tersebut diatas dapat berjalan dengan baik maka dapat meningkatkan kinerja pegawai.

Kinerja pegawai adalah kemampuan kerja atau hasil kerja yang dapat diamati melalui dimensi kualitas, kuantitas dan ketetapan waktu menyelesaikan pekerjaan. Kualitas kerja berkaitan dengan ketetapan mutu hasil pelaksanaan pekerjaan, tingkat kesalahan prosedur dalam pelaksanaan pekerjaan serta frekuensi teguran pimpinan atas mutu hasil pekerjaan. Kuantitas kerja berkaitan dengan ketetapan volume hasil kerja, ketetapan penggunaan fasilitas dari frekuensi teguran pimpinan atas pencapaian volume hasil kerja. Ketetapan waktu menyelesaikan pekerjaan berkaitan dengan ketetapan waktu memulai pelaksanaan pekerjaan, ketetapan penyelesaian pekerjaan dan frekuensi teguran pimpinan atas keterlambatan penyelesaian pekerjaan.

Dalam melaksanakan tugas pokok dan fungsinya, LPMP Sultra didukung oleh 123 pegawai dengan volume tugas dan beban pekerjaan yang tidak sama. Kinerja pegawai Lembaga Penjaminan Mutu Pendidikan Provinsi Sulawesi Tenggara yang ada saat ini belum optimal. Dalam hal menyelesaikan pekerjaan, masih dijumpai pegawai yang tidak tepat waktu dalam mengerjakan pekerjaan. Selain itu masih ditemukan adanya pendistribusian pekerjaan yang tidak merata. Hal ini terlihat dalam beberapa hal seperti ada pegawai yang bekerja selama jam kerja, dan disisi lain ada juga pegawai yang tidak bekerja selama jam kerja.

Pengamatan awal didapatkan data bahwa kinerja aparatur pada instansi tersebut belum sepenuhnya sesuai yang diharapkan bila ditinjau dari dimensi kualitas, kuantitas kerja serta ketepatan waktu menyelesaikan pekerjaan. Pada dimensi kualitas kerja antara lain bahwa pegawai harus selalu diperintah dalam 
menyelesaikan tugas yang menjadi kewajibannya, bekerja tidak tepat waktu yang ditandai dengan terlambat masuk kantor, pulang sebelum waktunya dan pada saat jam kantor sedang berlangsung terlihat tidak bekerja. Selanjutnya pada dimensi kuantitas kerja terlihat bahwa pelayanan prima kepada masyarakat belum teraplikasi dengan baik yaitu pelayanan terkesan lambat. Pada dimensi ketepatan waktu masih terlihat adanya tunggakan kerja, misalnya yang seharusnya pekerjaan selesai pada hari itu namun dalam kenyataan diselesaikan keesokan harinya. Contohnya adalah adanya beberapa pegawai yang seharusnya dapat mencetak laporan hasil kegiatannya pada hari senin, namun kemudian pegawai dimaksud menundanya sampai hari selasa, padahal jika diselesaikan pada hari senin, maka pada hari selasa pegawai bersangkutan dapat menyelesaikan pekerjaan yang lain.

Kondisi atau fenomena tersebut merupakan salah satu dari sekian banyak fakta yang terjadi, diduga ada kaitannya dengan pemberian motivasi serta iklim organisasi yang belum optimal, namun demikian masih perlu diteliti lebih jauh secara empiris.

Berdasarkan latar belakang tersebut maka penulis akan meneliti tentang sejauh mana motivasi dan iklim organisasi dalam memediasi peningkatan kinerja Pegawai Negeri Sipil pada Lembaga Penjaminan Mutu Pendidikan Provinsi Sulawesi Tenggara.

\section{RUMUSAN MASALAH}

Bertolak pada latar belakang tersebut, rumusan masalah sebagai berikut :

1. Apakah motivasi berpengaruh positif dan signifikan terhadap kinerja pegawai Lembaga Penjaminan Mutu Pendidikan Provinsi Sulawesi Tenggara?

2. Apakah iklim organisasi berpengaruh positif dan signifikan terhadap kinerja pegawai Lembaga Penjaminan Mutu Pendidikan Provinsi Sulawesi Tenggara?

3. Apakah motivasi dan iklim organisasi berpengaruh positif dan signifikan secara bersama-sama terhadap kinerja pegawai Lembaga Penjaminan Mutu Pendidikan Provinsi Sulawesi Tenggara?

\section{KAJIAN TEORI}

\section{Konsep Motivasi}

Manullang (2001:165-166) menjelaskan pengertian dari beberapa istilah yang berkaitan dengan motivasi yaitu motif dan motivasi. Motif adalah tenaga pendorong yang mendorong manusia untuk bertindak, sedangkan motivasi menurut arti katanya berarti pemberian motif, penimbulan motif atau hal yang menimbulkan dorongan.

Nawawi (2001:35) memberikan pengertian bahwa, kata motivasi (Motivation)yang berarti dorongan, sebab atau alasan seseorang melakukan sesuatu. Dengan demikian motivasi berarti suatu kondisi yang mendorong atau menjadi sebab seseorang melakukan suatu perbuatan atau kegiatan yang berlangsung secara sadar. Motif seringkali diartikan dengan istilah dorongan. Dorongan atau tenaga tersebut merupakan gerak jiwa dan jasmani untuk berbuat, sehingga motif tersebut merupakan driving force yang menggerakkan manusia untuk bertingkah laku dan didalam perbuatannya itu mempunyai tujuan tertentu As'ad (1991:45) sehingga tubuh digerakkan oleh adanya kemauan untuk bertindak dari motif.

Dalam konteks pekerjaan, motivasi merupakan salah satu faktor penting dalam mendorong seorang karyawan untuk bekerja. Motivasi adalah kesediaan individu untuk mengeluarkan upaya yang tinggi untuk mencapai tujuan organisasi (Robbins, 1996). Ada tiga elemen kunci dalam motivasi yaitu upaya, tujuan organisasi dan kebutuhan. Upaya merupakan ukuran intensitas, bila seseorang termotivasi maka ia akan berupaya sekuat tenaga untuk mencapai tujuan, namun belum tentu upaya yang tinggi akan menghasilkan kinerja yang tinggi. Oleh karena itu diperlukan intensitas dan kualitas dari upaya tersebut serta difokuskan pada tujuan organisasi. 
Kebutuhan adalah kondisi internal yang menimbulkan dorongan, dimana kebutuhan yang tidak terpuaskan akan menimbulkan tegangan yang merangsang dorongan dari dalam diri individu. Dorongan ini menimbulkan perilaku pencarian untuk menemukan tujuan tertentu. Apabila ternyata terjadi pemenuhan kebutuhan, maka akan terjadi pengurangan tegangan. Pada dasarnya, karyawan yang termotivasi berada dalam kondisi tegang dan berupaya mengurangi ketegangan dengan mengeluarkan upaya.

Setyadi (2003:69) mengemukakan bahwa motivasi merupakan kunci keberhasilan dalam suatu organisasi karena efektif dan optimalnya kegiatan-kegiatan yang dilakukan akan ditentukan oleh ada atau tidak adanya motivasi kerja untuk mewujudkannya. Inti motivasi kerja adalah adanya peningkatan semangat kerja dan penjurusan aktifitas kerja pegawai agar mampu mewujudkan maksud yang dikehendaki oleh organisasi.

Berdasarkan pengertian-pengertian diatas dapat disimpulkan bahwa motivasi adalah suatu upaya yang terdapat didalam diri manusia yang menimbulkan, mengarahkan dan mengorganisasikan tingkah lakunya dalam memenuhi kebutuhan yang telah ditentukan sebelumnya, maka dapat didefinisikan bahwa motivasi adalah suatu upaya yang terdapat didalam diri manusia yang menimbulkan, mengarahkan dan mengorganisasikan tingkah laku didalam menjalankan tugas dan fungsinya agar mencapai tujuan yang ditargetkan oleh organisasi.

Hasibuan (2000:142) mengemukakan bahwa motivasi adalah pemberian daya penggerak yang menciptakan kegairahan seseorang agar mereka mau bekerja sama, bekerja efektif dan terintegrasi dengan segala daya upayanya untuk mencapai kepuasan, sehingga motivasi mempersoalkan bagaimana caranya mengarahkan daya dan potensi bawahannya agar mau bekerjasama secara produkktif, berhasil mencapai dan mewujutksn tujuan ysng telah ditentukan. Pentingnya motivasi karena motivasi adalah hal yang menyebabkan, menyalurkan dan mendukung perilaku manusia supaya mau bekerja giat dan antusias mencapai hasil yang optimal.

\section{Konsep Iklim Organisasi}

Setiap organisasi atau perusahaan memiliki cara tersendiri dalam menyajikan usahanya. Oleh karena itu suatu organisasi mempunyai iklim berbeda dengan organisasi lain. Iklim dapat bersifat menekan, netral atau dapat pula bersifat mendukung, tergantung bagaimana mengaturnya, karena itu setiap organisasi selalu mempunyai iklim kerja yang unik. Organisasi cenderung menarik dan mempertahankan orang-orang yang sesuai dengan iklim, sehingga dalam tingkatan tertentu polanya dapat langgeng.

Siagian (2004: 89) mengemukakan bahwa " Organisasi adalah setiap bentuk persekutuan antara dua orang atau lebih yang bekerja bersama serta secara formal terikat dalam rangka pencapaian suatu tujuan yang telah ditentukan, dalam ikatan nama terdapat seorang/beberapa orang yang disebut atasan dan seorang/sekelompok orang yang disebut bawahan".

Selanjutnya Atmosudirdjo (2006:81) mengemukakan bahwa organisasi adalah struktur tata pembagian kerja dan struktur tata hubungan kerja antara sekelompok orang-orang pemegang posisi yang bekerja sama secara tertentu untuk bersama-sama mencapai suatu tujuan tertentu"

Steers (1985:101 ) mengemukakan bahwa "organisasi adalah struktur tata pembagian kerja dan struktur tata hubungan kerja antara sekelompok orang-orang pemegang posisi yang bekerja sama secara tertentu untuk bersama-sama mencapai suatu tujuan tertentu"

Disamping itu organisasi dapat pula didefinisikan sebagai suatu himpunan interaksi manusia yang bekerja sama untuk mencapai tujuan bersama yang terikat, dalam suatu ketentuan yang telah disetujui bersama, 
sebagaimana telah disinggung, implikasi pengertian ini cukup luas namun demikian buku ini meninjau organisasi dari kacamata administrasi dan manajemen.

Menurut Gelade dan Ivery (2003:2) bahwa iklim organisasi adalah factor perantara bagi sumber daya manusia dengan kinerja organisasi. Praktek sumber daya manusia yang progresif akan mendorong suatu iklim organisasi yang positif, meningkatkan kesejahteraan dan motivasi karyawan yang selanjutnya mengarah pada penguatan kinerja unit-unit organisasi. Selanjutnya Gelade dan Iveri (2003:384) mengatakan bahwa iklim organisasi adalah interprestasi tentang lingkungan kerja oleh orang-orang yang berada didalamnya, pendapat ini menunjukkan bahwa iklim organisasi berbeda dengan lingkungan kerja. Lingkungan kerja adalah factor fisik sedangkan iklim organisasi adalah suasana psikologis dari orang yang berada didalam lingkungan kerja tersebut. Gelade dan Iveri (2003:385) memberikan contoh bahwa perubahan didalam kebijakan upah dan promosi dapat diharapkan mengubah persepsi karyawan tentang orientasi ganjaran dan kemungkinan adanya kesetaraan dan kejujuran, demikian juga introduksi program pelatihan sebagai praktek yang seringkali memperbaiki produktifitas, kemungkinan memberikan pengaruh positif pada persepsi karyawan tentang dukungan tugas. Iklim organisasi pada gilirannya mempengaruhi status koknitif (pengetahuan) dan efektif (perasaan) karyawan ditempat kerja.

Steers (1980) mengemukakan setidaknya ada 4 (empat) komponen yang menentukan suatu iklim organisasi, yaitu struktur kebijakan organisasi, teknologi, lingkungan luar, kebijakan dan praktek manajemen.

Setiap organisasi mempunyai iklim yang berbeda dengan organisasi lainnya. Simamora (2001:8) menyebutkan bahwa keanekaragaman pekerjaan yang dirancang didalam organisasi atau sifat individu yang ada akan menggambarkan perbedaan tersebut. Semua organisasi tentu memiliki strategi dalam memanajemeni sumber daya manusianya, iklim organisasi yang terbuka memacu karyawan untuk mengutarakan kepentingan dan ketidakpuasan tanpa adanya rasa takut akan tindakan balasan dan perhatian. Ketidakpuasan seperti itu dapat ditangani dengan cara yang positif dan bijaksana, iklim keterbukaan bagaimanapun juga hanya tercipta jika semua anggota memiliki tingkat keyakinan yang tinggi dan mempercayai keadilan tindakan.

Iklim organisasi juga berkenan dengan persepsi anggota organisasi, baik secara individual maupun kelompok, tentang sifat-sifat dan karakteristik organisasi yang mencerminkan norma serta keyakinan dalam organisasi, banyak hal yang berpengaruh di dalam organisasi sehingga terbentuklah iklim organisasi, hal tersebut adalah : a) bekerja keras, beban kerja yang berat serta tidak diimbangi dengan hasil yang diharapkan pada akhirnya juga akan mempengaruhi orang-orang yang ada didalam organisasi tersebut, b) kerja sama, antara pemimpin dan karyawan tidak saling membeda-bedakan, bersama-sama menciptakan suasana dalam organisasi menjadi nyaman sehingga kesertaan dan keserasian kerja didalamnya semakin meningkatkan kinerja organisasi tersebut, c) peraturan, yang dibuat dijadikan sebagai pedoman sehingga benar-benar mentaati dan bila ada penyelewengan harus benar-benar ditindak dengan tegas, baik memberikan peringatan ataupun hukuman.

\section{Konsep Kinerja Pegawai}

Kinerja merupakan hasil dari pekerjaan yang telah dilakukan oleh seseorang dan bekerja pada dasarnya merupakan hakekat hidup manusia dalam mengaktualisasikan potensi dirinya, dengan bekerja manusia akan dapat memenuhi kebutuhan-kebutuhan dasar dalam hidupnya selain itu juga dapat mengangkat derajat kesejahteraan diri dan keluarganya agar dapat hidup lebih aman, tentram dan berkesinambungan.

Menurut Winardi (2006:82) mengemukakan bahwa kinerja adalah kemampuan kerja seorang karyawan dalam menyelesaikan tugas yang dibebankan kepadanya secara berhasil dan berdaya guna. 
Menurut Dharma (2005:1) bahwa kinerja atau perestasi kerja adalah sesuatu yang dikerjakan atau produk jasajasa yang diberikan atau yang dihasilkan oleh seseorang atau kelompok orang.

Namun untuk unit kerja kelompok atau tim, kinerja tersebut agak sulit dalam hubungan ini Simamora (2004:79) mengemukakan bahwa prestasi kerja dapat dilihat dari indicator-indikator sebagai berikut : (1) keputusan terhadap segala aturan yang telah ditetapkan organisasi (2) dapat melaksanakan pekerjaan atau tugasnya tanpa kesalahan (atau dengan tingkat kesalahan yang paling rendah). (3) ketepatan dalam menjalankan tugas.

Prawirosentana (1999:34) mendefinisikan kinerja adalah hasil kerja yang dapat dicapai seseorang atau sekelompok orang dalam suatu organisasi sesuai dengan kewenangan dan tanggung jawab masing-masing dalam rangka upaya mencapai tujuan organisasi yang bersangkutan secara legal, tidak melanggar hukum dan sesuai dengan moral dan etika.

Konsep kinerja tersebut menekankan bahwa kinerja selalu berhubungan dengan hasil yang dicapai, baik secara perorangan maupun sebagai suatu organisasi. Agar kinerja perorangan maupun organisasi secara keseluruhan, maka tugas-tugas pemerintahan harus mengandung tiga unsur :

1. Kejelasan tugas yang menjadi tanggung jawab yang jelas.

2. Kejelasan hasil yang diharapkan dari suatu fungsi atau pelayanan.

3. Kaktu yang dibutuhkan untuk menyelesikan suatu fungsi agar yang diharapkan dapat terwujud.

Dengan demikian tinggi rendahnya kualitas kinerja pegawai dapat dinilai ketika sesuai dengan tiga hal tersebut.

Kemudian menurut Simamora (2004:432) mengemukakan bahwa prestasi kerja (performance) merupakan suatu pencapaian persyaratan pekerjaan tertentu yang akhirnya secara langsung dapat tercermin dari output yang dihasilkan baik kuantitas maupun kualitaasnya. Pengertian tersebut menyoroti prestasi kerja berdasarkan hasil yang dicapai seseorang setelah melakukan pekerjaan.

Handoko (2003:135) mengemukakan bahwa penilaian prestasi kerja adalah proses melalui mana organisasiorganisasi mengevaluasi atau menilai prestasi pegawainya. Kegiatan ini dapat mempengaruhi keputusankeputusan personalia dan memberikan umpan balik kepada para karyawan tentang pelaksanaan kerja mereka. Adapun kegunaan penilaian kinerja adalah sebagai berikut :

1. Mendorong orang ataupun karyawan agar berperilaku positif atau memperbaiki tindakan mereka yang dibawah standar.

2. Sebagai bahan penilaian yang kuat bagi manajemen apakah karyawan tersebut telah bekerja dengan baik

3. Memberikan dasar yang kuat bagi pembuatan kebijakan peningkatan organisasi.

Berdasarkan uraian tersebut, dapat disimpulkan bahwa penilaian prestasi kerja adalah proses suatu organisasi mengevaluasi atau menilai kerja pegawainya, apabila penilaian prestasi kerja dilaksanakan dengan baik, tertib dan benar akan dapat membantu meningkatkan motivasi kerja sekaligus dapat meningkatkan loyalitas para anggota organisasi yang ada didalamnya, maka akan menguntungkan organisasi itu sendiri. Oleh karena itu penilaian prestasi kerja perlu dilakukan secara formal dengan criteria yang telah ditetapkan oleh organisasi secara obyektif. 
Menurut Simamora (2004:107) mengemukakan penilaian prestasi kerja merupakan alat yang berbeda tidak hanya untuk mengevaluasi kerja para pegawai tetapi juga untuk mengembangkan dam memotivasi kalangan pegawai.

Simamora (2004:423) juga mengemukakan bahwa prestasi kerja (performance) merupakan suatu pencapaian persyaratan pekerjaan tertentu yang akhirnya secara langsung dapat tercermin dari output yang dihasilkan baik kuantitas maupun kualitasnya. Pengertian tersebut menyoroti prestasi kerja berdasarkan hasil yang dicapai seseorang setelah melakukan pekerjaan.

Tiffin yang dikutif Manullang (2001:118) member pembatasan bahwa penilaian pegawai adalah penilaian yang sistematis dari pada seorang pegawai oleh atasannya atau beberapa orang ahli lainnya yang faham akan pelaksanaan pekerjaan yang dilakukan oleh pegawai tersebut

Handoko (2003:135) mengemukakan bahwa penilaian prestasi kerja adalah proses melalui mana organisasiorganisasi mengevaluasi atau menilai prestasi pegawainya. Kegiatan ini dapat mempengaruhi keputusankeputusan personalia dan memberikan umpan balik kepada para karyawan tentang pelaksanan kerja mereka.

Kinerja juga merupakan titik kulminasi dari tiga elemen yang saling berkaitan yaitu : keterampilan, sifat keadaan, dan kondisi eksternal. Ada dua faktor yang mempengaruhi perilaku kerja yaitu : faktor eksternal individu seperti : kompetensi, kemampuan dan keterampilan, faktor internal individu seperti : keadaan ekonomi, kebijakan pemerintah, ketersediaan bahan dan sebagainya.

Benardin dan Rusel dalam Ruky (2002:15) memberikan definisi tentang prestasi kerja (performance) sebagai berikut : Performance is defined as the record of autcomes produced on a specified job function or activity during a specified time period (prestasi kerja adalah catatan tentang hasil-hasil yang diperoleh dari fungsi-fungsi pekerjaan tertentu atau kegiatan-kegiatan tertentu selama kurun waktu tertentu).

Prestasi kerja adalah sesuatu yang dikerjakan produk atau jasa yang dihasilkan oleh seseorang atau kelompok bagaimana kualitas kerja, ketelitian dan kerapihan kerja, penugasan dan bidang kerja, penggunaan dan pemeliharaan peralatan, inisiatif dan kreatifitas, disiplin dan semangat kerja (kejujuran, loyalitas,rasa kesatuan dan tanggung jawab serta hubungan antar pribadi).

Benardin dan Rusel dalam Ruky (2002:340) juga mengemukkan beberapa kriteria primer yang dapat digunakan untuk mengukur kinerja, yaitu

1. Quality adalah tanggung jawab dan wewenang yang diemban, ketepatan, ketelitian, keterampilan dam bekerja serta kebersihan kerja.

2. Kuantitas kerja adalah pencapaian volume hasil pekerjaan dan ketepatan penggunaan fasilitas/sarana kerja. Kuantitas kerja dapat diamati melalui indicator keluaran hasil kerja serta kecepatan dalam menyelesaikan pekerjaan.

3. Ketetapan waktu menyelesaian pekerjaan adalah ketepatan waktu memulai dan menyelesaikan pekerjaan.

Selanjutnya menurut Riduwan (2002:66-67) mengemukakan bahwa prestasi kerja seorang pegawai dapat diamati dari demensi: kualitas kerja, kuantitas kerja dan ketetapan waktu menyelesaikan pekerjaan. Lebih jelasnya diuraikan sebagai berikut :

1. Kualitas kerja adalah pencapaian mutu dan ketetapan prosedur dalam penyelasaikan pekerjaan. 
2. Variabel situasional: a) faktor fisik dan pekerjaan, terdiri dari: metode kerja, kondisi dan desaian perlengkapan kerja, penataan ruang dan lingkungan fisik; b) faktor sosial dan organisas, meliputi: peraturan-peraturan organisasi, jenis latihan dan pengawasan, sistem upah daan lingkungan sosial.

\section{METODE PENELITIAN}

\section{A. Desain Penelitian}

Desain penelitian ini menggunakan desain kuantitatif dengan cara pengambilan sampel. Alat pengumpul data berupa kuesioner dan wawancara yang relevan.

\section{B. Variabel Penelitian}

Variabel penelitian ini adalah:

1. Variabel bebas (independent) yaitu motivasi $\left(\mathrm{X}_{1}\right)$ dan iklim organisasi $\left(\mathrm{X}_{2}\right)$

2. Variabel terikat (dependent) yaitu kinerja pegawai.

\section{Populasi dan Sampel Penelitian}

Populasi dalam penelitian ini adalah keseluruhan pejabat dan karyawan Lembaga Penjaminan Mutu Pendidikan Provinsi Sulawesi Tenggara yang berjumlah 123 orang. Besarnya ukuran sampel dalam penelitian ini akan dicari dengan menggunakan rumus Slovin (Sugiyono, 2002) dengan tingkat kepercayaan 99 \%, dan diperoleh ukuran sampel sebanyak 56 orang pegawai.

\section{Teknik Pengumpulan Data}

Teknik pengambilan data dalam penelitian ini menggunakan teknik kuesioner, wawancara dan studi dokumentasi.

1. Kuesioner dalam bentuk angket yaitu mengedarkan angket kepada pegawai Lembaga Penjaminan Mutu Pendidikan Provinsi Sulawesi Tenggara yang terpilih menjadi sampel, dengan tujuan untuk mendapatkan data penelitian tentang pemberian motivasi, iklim organisasi dan kinerja pegawai Lembaga Penjaminan Mutu Pendidikan Provinsi Sulawesi Tenggara.

2. Wawancara, yaitu melakukan wawancara denga Kepala Lembaga Penjaminan Mutu Pendidikan Provinsi Sulawesi Tenggara sebagai top manajemen tentang pemberian motivasi, iklim organisasi dan kinerja pegawai Lembaga Penjaminan Mutu Pendidikan Provinsi Sulawesi Tenggara

3. Studi dokumentasi yaitu, mengumpulkan (menfotocopy) data -data yang berkaitan dengan esensi Lembaga Penjaminan Mutu Pendidikan Provinsi Sulawesi Tenggara

\section{E. Skala Pengukuran Variabel}

Angket menggunakan bobot skala Likert. Angket terdiri dari 5 (lima) alternatif jawaban yaitu: sangat setuju, setuju, netral, tidak setuju dan sangat tidak setuju. Untuk setiap pernyataan positif diberi bobot sebagai berikut: alternatif jawaban a diberi bobot 5, alternatif jawaban b diberi bobot 4, alternatif jawaban c diberi bobot 3 , alternatif jawaban d diberi bobot 2, alternatif jawaban e diberi bobot 1 . Sedangkan untuk pernyataan negatif diberi bobot sebaliknya.

\section{F. Uji Validitas dan Reliabilitas}

Uji Validitas: Analisis ini bertujuan untuk mendapatkan tingkat validitas setiap butir instrumen dan reliabilitas instrumen. 
Uji Reliabilitas: Uji reliabilitas menggunakan rumus Alpha - Cronbach sebagai berikut:

Keterangan rumus:

$\mathrm{k}$

$=$ jumlah item angket yang valid

$=$ jumlah varians item angket yang valid

$=$ jumlah varians total angket

Dengan kriteria pengambilan keputusan $r_{11}$ hitung $\geq r_{11}$ tabel, maka disimpulkan angket reliabel.

\section{H. .Teknik Analisa Data}

Teknik analisa data dalam penelitian ini dilakukan dengan langkah sebagai berikut:

1. Analisa data deskriptif. Analisa deskriptif yang dilakukan adalah ukuran tendensi pusat yang meliputi mean, modus, median. Selanjutnya untuk pengkategorian variabel menggunakan kategori sebagai berikut:

4, 20 sampai dengan 5, 00 kategori sangat baik

3,40 sampai dengan 4, 19 kategori baik

2, 60 sampai dengan 3, 39 kategori cukup baik

1, 80 sampai dengan 2, 59 kategori kurang baik

1, 00 sampai dengan 1, 79 kategori sangat kurang baik (Thoha, 1991:100)

2. Analisa data inferensial. Sebelum data dianalisa secara inferensial. Analisa data inferensial yang dilakukan adalah analisa regresi linier berganda.

\section{HASIL PENELITIAN DAN PEMBAHASAN}

\section{Rancangan Uji Hipotesis}

Rancangan Uji Hipotesis antar variabel X dengan Y serta criteria penerimaannya adalah sebagai berikut:

Ho: Motivasi tidak berpengaruh positif dan signifikan terhadap kinerja pegawai Lembaga Penjaminan Mutu Pendidikan Provinsi Sulawesi Tenggara

Hl: Motivasi berpengaruh positif dan signifikan terhadap kinerja pegawai Lembaga Penjaminan Mutu Pendidikan Provinsi Sulawesi Tenggara

Ho: Iklim organisasi tidak berpengaruh positif dan signifikan terhadap kinerja pegawai Lembaga Penjaminan Mutu Pendidikan Provinsi Sulawesi Tenggara.

Hl: Iklim organisasi berpengaruh positif dan signifikan terhadap kinerja pegawai Lembaga Penjaminan Mutu Pendidikan Provinsi Sulawesi Tenggara.

Ho: Motivasi dan iklim organisasi secara bersama - sama tidak berpengaruh positif dan signifikan terhadap kinerja pegawai Lembaga Penjaminan Mutu Pendidikan Provinsi Sulawesi Tenggara.

Hl: Motivasi dan iklim organisasi secara bersama - sama berpengaruh positif dan signifikan terhadap kinerja pegawai Lembaga Penjaminan Mutu Pendidikan Provinsi Sulawesi Tenggara.

Pengujian hipotesis dilakukan secara simultan maupun secara parsial. Uji simultan digunakan untuk mengetahui pengaruh motivasi dan iklim organisasi secara bersama - sama terhadap kinerja, sedangkan uji parsial untuk mengetahui pengaruh motivasi dan iklim organisasi terhadap kinerja secara terpisah.

Untuk uji simultan, menggunakan uji $F$, dengan cara membandingkan nilai $F$ hitung dengan $F$ tabel. Tingkat kepercayaan yang digunakan dalam penelitian ini adalah $95 \%$ atau taraf nyata 0,05 . Hal ini berarti hasil penelitian yang diperoleh hanya dapat dipercaya sebesar $95 \%$ dan $5 \%$ sisa adalah bias dari penelitian ini. Kriteria pengambilan keputusan untuk uji hipotesis simultan adalah : 
Jika $F_{\text {hit }} \geq \mathrm{F}_{\text {tabs }}$ maka hipotesis alternatif diterima atau $\mathrm{H}_{0}$ ditolak,

Jika $\mathrm{F}_{\text {hit }}<\mathrm{F}_{\text {tab, }}$ maka hipotesis alternatif ditolak atau $\mathrm{H}_{0}$ diterima.

Sedangkan untuk tingkat korelasi variabel motivasi dan iklim organisasi secara bersama - sama terhadap kinerja ditentukan dengan nilai Koefisien Korelasi Ganda (R), dengan kategori sebagai berikut:

$0,00-0,20$ tidak ada korelasi

$0,21-0,40$ korelasi lemah

$0,41-0,60$ korelasi sedang

$0,61-0,80$ korelasi kuat

$0,81-1,00$ korelasi sangat kuat.

Selanjutnya untuk menentukan besarnya pengaruh variabel motivasi dan iklim organisasi secara bersama sama terhadap kinerja ditentukan dengan nilai Koefisien Determinasi Ganda.

Sedangkan untuk uji hipotesis parsial menggunakan uji t. Tingkat kepercayaan yang digunakan dalam penelitian ini adalah $95 \%$ atau taraf nyata 0,05 . Hal ini berarti hasil penelitian yang diperoleh hanya dapat dipercaya sebesar $95 \%$ dan $5 \%$ sisa adalah bias dari penelitian ini.

Kriteria pengambilan keputusan untuk uji hipotesis parsial adalah :

Jika $\mathrm{t}_{\text {hit }} \geq \mathrm{t}_{\mathrm{tab}}$, maka hipotesis alternatif diterima atau $\mathrm{H}_{0}$ ditolak,

Jika $t_{\text {hit }}<\mathrm{t}_{\text {tab }}$, maka hipotesis alternatif ditolak atau $\mathrm{H}_{0}$ diterima.

Selanjutnya nilai - nilai yang diperoleh pada hasil analisis akan diterjemahkan dan dibandingkan dengan kenyataan empirisdan kajian - kajian teori yang relevan.

Berdasarkan hasil analisis data diperoleh nilai koefisien korelasi ganda (R) sebesar 0,273. Hal ini menginterpretasikan 27,30 \% variasi yang terjadi pada variabel kinerja Lembaga Penjaminan Mutu Pendidikan Provinsi Sulawesi Tenggara (Y) dapat dijelaskan oleh variabel motivasi dan iklim organisasi dengan persamaan regresi kinerja $(\mathrm{Y})$ atas motivasi dan iklim organisasi yaitu . Sedangkan $72.70 \%$ ditentukan oleh variabel lain.

Untuk dapat mencapai tujuan organisasi dalam rangka mewujudkan visi dan misi, maka peran pegawai sebagai salah satu komponen penting dalam organisasi merupakan suatu hal yang perlu mendapat perhatian untuk selalu dikaji dalam upaya menemukan suatu cara untuk menciptakan suatu kondisi kerja yang dapat menjamin bahwa proses kerja pegawai dapat terlaksana sesuai dengan aturan dan nilai yang disepakati serta kinerja pegawai dapat mencapai tujuan organisasi.

Dinamika lingkungan kerja baik ditinjau dari segi lingkungan kerja, personil kerja maupun sarana prasarana kerja, secara sadar ataupun tak sadar akan menjadi salah satu faktor yang akan mempengaruhi proses kerja pegawai yang kemudian akan bermuara pada perubahan kinerja pegawai. Dalam hal ini, tentunya menuntut organisasi untuk selalu menciptakan suasana kerja yang kondusif yang dapat menunjang proses pelaksanaan kerja pegawai sehingga dinamika yang terjadi akan membawa dampak yang positif terhadap organisasi.

Hal ini menggambarkan tentang pentingnya pihak manajemen untuk memotivasi pegawai, sehingga pegawai dapat melaksanakan tugasnya dengan kualitas proses yang baik sehingga akan berdampak pada peningkatan kinerja lembaga.

Pemberian motivasi dapat dilakukan dengan memberikan bonus atau honor yang layak, menempatkan pegawai yang sesuai dengan kompetensinya, menciptakan kondisi lingkungan kerja yang nyaman, memperhatikan pengakuan harga diri sebagai individu manusia dan pegawai, perlakuan yang adil dan tak sewenang-wenang serta memberikan kesempatan kepada pegawai untuk meningkatkan jenjang pendidikannya dan mengembangkan keterampilannya.

Walaupun pada kenyataannya, lembaga telah melaksanakan hal - hal dimaksud dalam pemberian motivasi terhadap pegawai, namun ditinjau secara statitstik berdasarkan kategori deskriptif bahwa secara umum pemberian motivasi di kantor Lembaga Penjaminan Mutu Pendidikan Provinsi Sulawesi Tenggara 
masih belum mencapai kategori maksimal atau belum mencapai kategori sangat baik. Sehingga, berdasarkan hal itu diharapkan kepada pihak manajemen lembaga untuk terus meningkatkan kualitas dan kuantitas pemberian motivasi kepada pegawai dalam upaya meningkatkan kinerja Lembaga Penjaminan Mutu Pendidikan Provinsi Sulawesi Tenggara.

Berdasarkan hasil analisa data juga diperoleh gambaran bahwa betapa pentingnya pihak manajemen untuk menciptakan iklim organisasi yang kondusif, sehingga pegawai merasa luwes dan nyaman untuk bekerja. Iklim organisasi yang kondusif tidak terbentuk secara alami dan begitu saja, tetapi menuntut pihak manajemen untuk berupaya menciptakannya, walaupun disadari bahwa sangat sulit untuk menciptakan suatu iklim yang benar - benar kondusif, mengingat dalam sebuah organisasi memuat heteroganitas individu dengan berbagai kakater yang berbeda.

Walaupun pada kenyataannya, lembaga telah melaksanakan hal - hal dimaksud dalam rangka menicptakan iklim organisasi yang kondusif, namun ditinjau secara statitstik berdasarkan kategori deskriptif bahwa secara umum iklim organisasi di kantor Lembaga Penjaminan Mutu Pendidikan Provinsi Sulawesi Tenggara masih belum mencapai kategori maksimal atau belum mencapai kategori sangat baik. Sehingga, berdasarkan hal itu diharapkan kepada pihak manajemen lembaga untuk terus meningkatkan kualitas dan kuantitas menciptakan iklim organisasi yang kondusif dalam upaya meningkatkan kinerja Lembaga Penjaminan Mutu Pendidikan Provinsi Sulawesi Tenggara.

Pada salah satu tulisannya Robbins (1991) secara detil menjelaskan bahwa sala satu hal yang dinyatakannya sebagai faktor - faktor iklim organisasi yaitu Management support, yaitu tingkat kejelasan komunikasi, bantuan dan dukungan yang disediakan manajemen terhadap unit kerja di bawahnya.

Berdasarkan hasil analisa data juga diperoleh bahwa baik secara parsial maupun secara simultan, variabel motivasi dan iklim organisasi berpengaruh positif dan signifikan terhadap kinerja pegawai di Lembaga Penjaminan Mutu Pendidikan Provinsi Sulawesi Tenggara. Hal ini menginterpretasikan bahwa dinamika perubahan yang terjadi pada organisasi yang disebabkan oleh pemberian motivasi dan iklim organisasi yang kondusif akan mempengaruhi kinerja pegawai Lembaga Penjaminan Mutu Pendidikan Provinsi Sulawesi Tenggara.

Motivasi dan iklim organisasi terhadap kinerja berpengaruh positif yang berarti bahwa terjadi perubahan yang linear antara ketiga variabel tersebut. Artinya, bahwa jika kualitas dan kuantitas pemberian motivasi terus ditingkatkan, maka kinerja akan mengalami peningkatan juga. Demikian juga, jika kualitas dan kuantitas iklim organisasi yang kondusif terus ditingkatkan, maka kinerja pegawai akan mengalami peningkatan juga.

Pemberian motivasi yang meliputi dimensi pemberian insetif, penempatan pegawai pada bidang yang sesuai, perhatian terhadap lingkunga kerja, perhatian terhadap harga diri dan pemberian kesempatan untuk maju kepada pegawai jika berada pada kondisi yang baik, maka akan berpengaruh terhadap kinerja pegawai dan sebaliknya jika dimensi - dimensi di atas berada pada keadaan yang kurang baik maka akan mengakibatkan penurunan kinerja pegawai.

Demikian juga dengan kondisi iklim organisasi kondusif yang meliputi keluwesan pegawai dalam bekerja, penghargaan atas kerja dan kejelasan pekerjaan apabila berada pada kondisi yang yang baik , maka akan memberikan pengaruh yang baik dan positif terhadap kinerja pegawai. Hal ini sejalan dengan yang dikemukakan oleh Gelade dan Ivery (2003:2) bahwa iklim organisasi adalah factor perantara bagi sumber daya manusia dengan kinerja organisasi. Praktek sumber daya manusia yang progresif akan mendorong suatu iklim organisasi yang positif, meningkatkan kesejahteraan dan motivasi karyawan yang selanjutnya mengarah pada penguatan kinerja unit-unit organisasi.

Walaupun variabel motivasi dan iklim organisasi berpengaruh positif dan signifikan terhadap kinerja pegawai di Lembaga Penjaminan Mutu Pendidikan Provinsi Sulawesi Tenggara, namun secara statistik bahwa derajat hubungan antara variabel motivasi dan iklim organisasi berpengaruh positif dan signifikan terhadap 
kinerja pegawai di Lembaga Penjaminan Mutu Pendidikan Provinsi Sulawesi Tenggara masih berada pada kategori sedang.

Hal ini tentunya menjadi tugas bagi manajemen untuk terus meningkatkan kualitasdan kuantitas pemberian motivasi dan menciptakan iklim organisasi yang kondusif, sehingga variabel pemberian motivasi dan iklim organisasi dapat menunjukkan hubungan yang sangat kuat dengan kinerja pegawai di Lembaga Penjaminan Mutu Pendidikan Provinsi Sulawesi Tenggara. Lembaga seyogianya lebih intens untuk memberikan motivasi kepada pegawai sehingga pegawai dapat memaksimalkan kemampuannya dalam bekerja. Disamping itu pula lembaga harus lebih intens untuk menciptakan kondisi iklim organisasi yang kondusif sehingga pegawai merasa nyaman bekerja di kantor.

Besarnya pengaruh yang diberikan oleh variabel pemberian motivasi dan iklim organisasi sebesar 27, $30 \%$. Hal ini berarti dari sekian besarnya perubahan kinerja, maka $27,30 \%$ dipengaruhi oleh pemberian motivasi dan iklim organisasi. Sedangkan 72,70 \% dipengaruhi oleh faktor lain.

Hasil penelitian ini menguatkan hasil penelitian sebelumnya yaitu Wadji Farid M. (2005) variabel motivasi mempunyai pengaruh yang positif terhadap kinerja pegawai. Selanjutnya hasil penelitian oleh Samaria (2008:9-41) yang mengemukakan bahwa ikilim organisasi berpengaruh kuat dan positif serta signifikan terhadap kinerja pegawai I sekretariat daerah Kabupaten Muna. Juga penelitian La Ode Husman (2008), yang membuktikan motivasi kerja dan iklim organisasi berpengaruh positif terhadap kinerja aparatur dinas pekerjaan umum Kabupaten Muna. Penelitian oleh Muhardin (2011) menemukan adanya pengaruh positif motivasi kerja dan iklim organisasi terhadap kinerja aparatur dinas koperasi dan UKM Kabupaten Muna.

Pembahasan hasil penelitian tentang variabel pemberian motivasi dan iklim organisasi terhadap kinerja pegawai di Lembaga Penjaminan Mutu Pendidikan Provinsi Sulawesi Tenggara, yang telah membuktikan bahwa:

1. Pemberian motivasi berpengaruh positif dan signifikan terhadap kinerja pegawai di Lembaga Penjaminan Mutu Pendidikan Provinsi Sulawesi Tenggara;

2. Iklim organisasi berpengaruh positif dan signifikan terhadap kinerja pegawai di Lembaga Penjaminan Mutu Pendidikan Provinsi Sulawesi Tenggara;

3. Pemberian motivasi daniklim organisasi secara bersama - sama berpengaruh positif dan signifikan terhadap kinerja pegawai di Lembaga Penjaminan Mutu Pendidikan Provinsi Sulawesi Tenggara.

Hasil penelitian ini secara statistik hanya dapat diterima pada tingkat kepercayaan $95 \%$ dan $5 \%$ lainnya adalah batas toleransi bias yang terjadi selama penelitian.

\section{KESIMPULAN}

Berdasarkan hasil analisis data penelitian dan pembahasan, dapat ditarik beberapa kesimpulan sebagai berikut:

1. Motivasi berpengaruh positif dan signifikan terhadap kinerja pegawai Lembaga Penjaminan Mutu Pendidikan Provinsi Sulawesi Tenggara.

2. Iklim organisasi berpengaruh positif dan signifikan terhadap kinerja pegawai Lembaga Penjaminan Mutu Pendidikan Provinsi Sulawesi Tenggara.

3. Motivasi dan iklim organisasi secara bersama - sama berpengaruh positif dan signifikan terhadap kinerja pegawai Lembaga Penjaminan Mutu Pendidikan Provinsi Sulawesi Tenggara. Ini berarti bahwa pemberian motivasi dan iklim organisasi yang kondusif akan memberikan dampak positif dan signifikan terhadap kinerja apabila ditnjau dari kualitas, kuantitas dan ketepatan waktu bekerja pegawai di Lembaga Penjaminan Mutu Pendidikan Provinsi Sulawesi Tenggara. 


\section{SARAN}

Berdasarkan hasil analisis data penelitian dan pembahasan, dapat disarankan beberapa hal, yaitu:

1. Diharapkan kepada Kepala Lembaga Penjaminan Mutu Pendidikan Provinsi Sulawesi Tenggara sebagai top manajemen untuk terus melakukan penguatan terhadap pemberian motivasi kepada pegawai. Misalnya dengan pemberian insentif, penempatan pada bidang yang sesuai, perhatian terhadap lingkungan kinerja, kebutuhan perhatian terhadap harga diri serta kesempatan untuk maju, ataupun memungkinkan dengan cara - cara memotivasi yang lain.

2. Diharapkan kepada Kepala Lembaga Penjaminan Mutu Pendidikan Provinsi Sulawesi Tenggara sebagai top manajemen untuk terus melakukan penguatan terhadap penciptaan suatu kondisi iklim organisasi yang kondusif. Misalnya dengan memberikan keleluasaan dan keselarasan penyesuaian diri, penghargaan atas kerja yang baik dan kejelasan pekerjaan.

3. Walaupun kategori motivasi dan iklim organisasi serta kinerja di pegawai Lembaga Penjaminan Mutu Pendidikan Provinsi Sulawesi Tenggara sudah baik, namun berdasarkan analisis secara statistik masih belum mencapai kriteria sangat baik, sehingga diharapkan kepada pegawai Lembaga Penjaminan Mutu Pendidikan Provinsi Sulawesi Tenggara untuk terus meningkatkan kualitas dan kuantitas kerjanya dalam rangka mencapai tujuan lembaga secara umum.

\section{DAFTAR PUSTAKA}

Atmosudirdjo, Prajudi.2006.Dasar - Dasar Organisasi Manajemen dengan Office Management. Jakarta. Rineka Cipta.

As'ad, Muhammad, 2001, Kinerja sebagai Media Peningkatan Derajat Dalam Konteks Industrialisasi, Ganeca, Bandung.

Dharma, Agus, 2005, Manajemen Prestasi Kerja, Jakarta, Ghalia Indonesia

Glade, Garry, A, Ivery, Mark, 2003.The Impact of Human Resourse Management and Work Climate on Organization Performance, Personnel Psychology, 56,383,409

Handoko, Hani T.1995.Manajemen Edisi 2. Yogiakarta.BPFE

Handoko.2004.Pengaruh Upah Terhadap Motivasi Kerja Karyawan, UGM.Press, Yogyakartaan.

Hasibuan, SP Malayu, 2000, Organisasi dan Motivasi. Jakarta PT.Bumi Aksara.

Manullang, M.2001. Manajemen Personalia. Jakarta. Aksara Baru.

Nawawi, Hadari, 2001, MSDM untuk Bisnis yang Kompetitif, Gajah Mada University Press. Yogyakarta 
Prawirosentana, Suyadi.1999. Analisis Kinerja Organisasi, Bandung, PT Remaja Rosdakarya. Bandung. PT Rineka Cipta.

Reksohadiprodjo, Sukanto dan Handoko T.Hani, 1997, Organisasi Perusahaan, Yogyakarta, BPFE

Riduwan.2002. Skala Pengukuran Variabel - Variabel Penelitian. Bandung. Alfa Beta.

Ruky Achmad S, 2002, Sistem Manajemen Kinerja di download dari : http//www.adln.geocitios.com.

Robins, P. Stephan.1996.Teori Organisasi Struktur, Desain dan Aplikasi. Jakarta.Alih Bahasa Yusuf Udana, Arcan.

Setyadi, Iwan, 2003, Memperkenalkan Manajemen Personalia Dalam Praktek, Jakarta, reneka Cipta.

Siagian, Sondang P.2004. Teori dan Praktek Kepemimpinan. Jakarta.Rineka Cipta.

Simamora, Henry.2004.Manajemen Sumber Daya Manusia. Yogyakarta.STIE.YKPN.

Simamora, Henry.2001. Manajemen dan Organisasi.Yogyakarta. STIE, YKPN

Steers, Richard M.1985.Efektifitas Organisasi, Terjemahan Magdalena Jamin.Jakarta. Erlangga.

Thoha.1991, Chabib.1991. Teknik Evaluasi Pendidikan. Jakarta. Rajawali Press.

Winardi.2006. Manajemen Perkantoran dan Pengawasan. Bandung. 